This Section of Epidemiology and Psychiatric Sciences appears in each issue of the Journal to stress the relevance of epidemiology for behavioral neurosciences, reporting the results of studies that explore the use of an epidemiological approach to provide a better understanding of the neural basis of major psychiatric disorders and, in turn, the utilisation of the behavioural neurosciences for promoting innovative epidemiological research.

The ultimate aim is to help the translation of most relevant research findings into every-day clinical practice. These contributions are written in house by the journal's editorial team or commissioned by the Section Editor (no more than 1000 words, short unstructured abstract, 4 key-words, one Table or Figure and up to ten references).

Paolo Brambilla, Section Editor

\title{
A review of altered biochemistry in the anterior cingulate cortex of first-episode psychosis
}

\author{
L. Squarcina ${ }^{1}$, J. A. Stanley ${ }^{2}$, M. Bellani ${ }^{3}$, C. A. Altamura ${ }^{4}$ and P. Brambilla ${ }^{4,5 *}$ \\ ${ }^{1}$ IRCCS 'E. Medea' Scientific Institute, Bosisio Parini, Italy \\ ${ }^{2}$ Department of Psychiatry \& Behavioral Neurosciences, School of Medicine, Wayne State University, Detroit, MI 48201, USA \\ ${ }^{3}$ Section of Psychiatry, AOUI Verona, Verona, Italy \\ ${ }^{4}$ Department of Neurosciences and Mental Health, Fondazione IRCCS Ca' Granda Ospedale Maggiore Policlinico, University of Milan, Milan, Italy \\ ${ }^{5}$ Department of Psychiatry and Behavioural Neurosciences, University of Texas at Houston, TX, USA
}

\begin{abstract}
Relevant biochemicals of the brain can be quantified in vivo, non-invasively, using proton Magnetic Resonance Spectroscopy ( ${ }^{1} \mathrm{H}$ MRS). This includes metabolites associated with neural general functioning, energetics, membrane phospholipid metabolism and neurotransmission. Moreover, there is substantial evidence of implication of the frontal and prefrontal areas in the pathogenesis of psychotic disorders such as schizophrenia. In particular, the anterior cingulate cortex (ACC) plays an important role in cognitive control of emotional and non-emotional processes. Thus the study of its extent of biochemistry dysfunction in the early stages of psychosis is of particular interest in gaining a greater understanding of its aetiology. In this review, we selected ${ }^{1} \mathrm{H}$ MRS studies focused on the ACC of first-episode psychosis (FEP). Four studies reported increased glutamatergic levels in FEP, while other four showed preserved concentrations. Moreover, findings on FEP do not fully mirror those in chronic patients. Due to conflicting findings, larger longitudinal ${ }^{1} \mathrm{H}$ MRS studies are expected to further explore glutamatergic neurotransmission in ACC of FEP in order to have a better understanding of the glutamatergic mechanisms underlying psychosis, possibly using ultra high field MR scanners.
\end{abstract}

Received 19 October 2016; Accepted 24 October 2016

Key words: Magnetic resonance spectroscopy, first episode psychosis, anterior cingulate cortex, brain biochemistry.

The study of first-episode psychosis (FEP) patients is of particular interest because it allows the investigation of neurobiological processes, ruling out the effects of long-term medications and chronicity (Squarcina

* Address for correspondence: P. Brambilla, Ph.D. M.D., Associate Professor of Psychiatry, University of Milan, Milan, Italy; Adjunct Associate Professor of Psychiatry, University of Texas at Houston, USA; Chair, EPA Neuroimaging Section; Dipartimento di Neuroscienze e Salute Mentale, U.O.C. Psichiatria (Pad. Alfieri), Fondazione IRCCS Ca' Granda Ospedale Maggiore Policlinico, Via Francesco Sforza 35-20122 Milan, Italy.

(Email: paolo.brambilla1@unimi.it) et al. 2015). Psychotic disorders are highly debilitating, with symptoms ranging from delusions and hallucinations to cognitive deficits (Altamura et al. 2015). In this context, Proton Magnetic Resonance Spectroscopy $\left({ }^{1} \mathrm{H}\right.$ MRS) is the only non-invasive imaging technique that can quantify the concentration of relevant biochemicals in vivo in localised brain areas such as the anterior cingulate cortex (ACC) (Benes \& Berretta, 2001; Stanley, 2002; Brambilla et al. 2005). The ${ }^{1} \mathrm{H}$ metabolites that are commonly reported include $\mathrm{N}$-acetylaspartate (NAA), a marker of functioning neurons (Stanley et al. 2007), phosphocreatine plus creatine $(\mathrm{PCr}+\mathrm{Cr})$, involved with energetic processes, 
glycerophosphocholine plus phosphocholine (GPC+ PC), catabolic and anabolic metabolites of membrane phospholipids, and neurotransmitters, glutamine, glutamate and gamma amino-butyric acid (GABA). ${ }^{1} \mathrm{H}$ MRS has been largely employed in psychosis with meta-analyses showing, in general, decreased NAA levels in schizophrenia in prefrontal and temporal areas (Kraguljac et al. 2012), while glutamate has been found to be altered in schizophrenia and in individuals with a high risk of developing the disease, especially in thalamus and prefrontal regions (Marsman et al. 2013; Merritt et al. 2013). The investigation of brain metabolites can therefore be of help in shedding light on the aetiology and biological mechanisms of psychosis.

Neuroanatomical models of schizophrenia are in agreement with the hypothesis of a frontal lobe biochemical alteration (Zabala et al. 2007). Thus, the study of prefrontal integrity and function in the early stages of the disease is of particular interest. The cingulate cortex, which is part of the cortico-striato-thalamocortical networks, is involved in various cognitive control and emotional processes. In particular, the evidence is compelling in implicating the ACC in the pathogenesis of schizophrenia (Baiano et al. 2007), particularly concerning negative symptoms (Hardy et al. 2011; Bersani et al. 2014). The neurobiology underlying psychosis is still unclear: MRS techniques could allow the identification of changes such as neuroplasticity or neuropil loss (Théberge et al. 2002). In this review, we consider studies, which focus on brain metabolites in the ACC of FEP patients measured with ${ }^{1} \mathrm{H}$ MRS. A bibliographic search on PUBMED on MRS studies exploring ACC in FEP was performed. The search terms used to identify the articles of interest were 'MRS', 'spectroscopy', 'anterior cingulate', 'first episode psychosis'. Ten papers, which have been summarised in Table 1, met these inclusion criteria.

Four out of the ten studies reported increased glutamatergic function (considered as glutamate, glutamine or glutamate plus glutamine) in FEP, whereas four studies showed preserved levels. Just one study reported changes in creatine (Tibbo et al. 2013). Going into details, Thèberge et al. (2002) found higher levels of glutamine, and no other metabolites, in the left anterior ACC of FEP, in accordance with the hypothesised abnormal glutamatergic activity in schizophrenia (Marsman et al. 2013). These results in FEP were confirmed in a 2007 study (Théberge et al. 2007): interestingly, glutamine levels did not decrease after 30 months of follow-up, suggesting that the lower levels found in chronic illness by the same group (Théberge et al. 2003), may need more time to appear. An association between glutamine and FEP has been highlighted also by the fact that its levels were found to be associated with patient performance in neuropsychological tests, such as the Wisconsin Card Sorting Test, the Paced Auditory Serial Addition Task and the Trail Making Test B (Dempster et al. 2015). An involvement of the glutamatergic function in the early stage of disease in frontal regions has also been confirmed by several studies, which found altered levels of glutamate. In particular, increased glutamate levels were reported in prefrontal areas of FEP (Smesny et al. 2015), including the anterior ACC. Smesny et al. (2015) hypothesised that glutamate is linked with cellular energy and membrane lipids metabolism, suggesting a relationship with membrane atypical behavior. This indicates that medication targeting neuroprotection could be of great importance especially at the early stages of disease. Levels of glutamate were found to be higher in non-remitted patients in respect to remitted patients, when compared after antipsychotic treatment, and to be associated with lower functioning and worse negative symptoms (Egerton et al. 2012). This indicates that the clinical status of patients could be related with glutamatergic dysfunction, which might then be targeted in patients, especially those not responding to antipsychotics. Results on glutamatergic function in FEP are not always in agreement, as some studies did not find differences between groups (Galinska et al. 2009; Tibbo et al. 2013). This could be related to the exact positioning of the voxel in the ACC. For example, Tibbo et al. (2013) positioned the voxel in the medial prefrontal region, including only part of anterior ACC. All studies considering NAA levels did not find any difference in the ACC of FEP compared with healthy subjects, even when finding differences in chronic schizophrenia patients (Natsubori et al. 2014), possibly indicating that neuronal integrity, linked with NAA, is related to the progression of disease.

Finally, Tibbo et al. (2013) reported a significant reduction in $\mathrm{PCr}+\mathrm{Cr}$ of $\mathrm{FEP}$ compared with controls. Both $\mathrm{PCr}$ and $\mathrm{Cr}$ are involved in the processes related with cellular energy: thus, the authors have hypothesised that schizophrenia is associated with dysregulation in maintaining adequate energy pools. Other studies which considered $\mathrm{PCr}+\mathrm{Cr}$ in their analyses (Théberge et al. 2002, 2007; Egerton et al. 2012; Tibbo et al. 2013; Natsubori et al. 2014; Dempster et al. 2015) reported pressured $\mathrm{PCr}+\mathrm{Cr}$ levels in FEP. It has to be noted though that Tibbo et al. (2013) utilised an ad-hoc MRS sequence with a long TE $(240 \mathrm{~ms})$ and the specific aim of quantifying mainly $\mathrm{Cr}$, which could be accounted for the difference in results in respect to the other studies.

In summary, although there are some findings on increased glutamatergic levels in the ACC of FEP, they are still partially conflicting since some ${ }^{1} \mathrm{H}$ MRS 
Table 1. Selection of studies on first-episode psychosis investigating anterior cingulate cortex metabolism with 1-H magnetic resonance spectroscopy

\begin{tabular}{|c|c|c|c|c|c|c|c|}
\hline Study & $\begin{array}{c}\text { Sample size } \\
\text { (mean age } \pm \text { S.D.) }\end{array}$ & Study design & $\begin{array}{l}\text { Field } \\
\text { strength }\end{array}$ & $\begin{array}{l}\text { SV or CSI and location } \\
\text { (voxel size) }\end{array}$ & $\begin{array}{l}\text { Short or } \\
\text { intermediate } \\
\text { Echo time } \\
\text { (TE time) }\end{array}$ & $\begin{array}{l}\text { Quantification } \\
\text { and reported }{ }^{1} \\
\text { H metabolites }\end{array}$ & $\begin{array}{l}\text { ACC results only (if possible, } \\
\text { include the effect size in } \\
\text { brackets for each } \\
\text { significant finding) }\end{array}$ \\
\hline $\begin{array}{l}\text { Théberge } \\
\text { et al. } \\
\text { (2002) }\end{array}$ & $\begin{array}{l}21 \text { FEP ( } 26 \pm 7 \text { y.o. }) \text {, } \\
21 \mathrm{HC}(26 \pm 7 \\
\text { y.o. })\end{array}$ & $\begin{array}{l}\text { Cross-sectional and investigated } \\
\text { group differences }\end{array}$ & $4 \mathrm{~T}$ & $\begin{array}{l}\text { SV } \\
\text { Left anterior ACC }(1.5 \mathrm{cc}) \text { and } \\
\text { left medial thalamus }(1.5 \mathrm{cc})\end{array}$ & Short TE (20 ms) & $\begin{array}{l}\text { Absolute relative } \\
\text { to water (only } \\
\text { NAA } \\
\text { Glu } \\
\text { Gln } \\
\text { GPC + PC } \\
\text { PCr + Cr } \\
\text { Taurine } \\
\text { scyllo-Ins } \\
\text { myo-Ins) }\end{array}$ & Increased Gln in the left ACC \\
\hline $\begin{array}{l}\text { Théberge } \\
\text { et al. } \\
\text { (2004) }\end{array}$ & 19 FEP ( $25 \pm 8$ y.o. $)$ & Cross-sectional & $4 \mathrm{~T}$ & $\begin{array}{l}\text { SV } \\
\text { Left anterior ACC and left } \\
\text { thalamus }(1.5 \mathrm{cc})\end{array}$ & Short TE (20 ms) & $\begin{array}{l}\text { Absolute relative } \\
\text { to water } \\
\text { NAA } \\
\text { GPC + PC }\end{array}$ & $\begin{array}{l}\text { Positive correlation between } \\
\text { GPC + PC and duration of } \\
\text { untreated psychosis }\end{array}$ \\
\hline $\begin{array}{l}\text { Blasi et al. } \\
\quad \text { (2004) }\end{array}$ & $\begin{array}{l}17 \text { FEP }(26.8 \pm 7.6 \\
\text { y.o. }), 17 \text { HC }(25.5 \\
\pm 6.8 \text { y.o. })\end{array}$ & $\begin{array}{l}\text { Cross-sectional and investigated } \\
\text { group differences }\end{array}$ & $1.5 \mathrm{~T}$ & $\begin{array}{l}\text { CSI }(7.5 \times 7.5 \times 15 \mathrm{~mm}-0.84 \\
\text { ml }) \\
\text { Four slices } \\
\text { Left and right } \\
\text { ACC }(0.84 \text { cc each }) \text { plus other } \\
\text { ROIs }\end{array}$ & $\begin{array}{l}\text { Long TE (272 } \\
\text { ms) }\end{array}$ & $\begin{array}{l}\text { Metabolite ratios } \\
\text { NAA/PCr + Cr } \\
\text { NAA/GPC + PC } \\
\text { GPC + PC/PCr } \\
+\mathrm{Cr}\end{array}$ & $\begin{array}{l}\text { No significant group } \\
\text { differences in the right and } \\
\text { left ACC }\end{array}$ \\
\hline $\begin{array}{l}\text { Théberge } \\
\text { et al. } \\
\text { (2007) }\end{array}$ & $\begin{array}{l}16 \text { FEP }(25 \pm 8 \text { y.o. }) \\
16 \text { HC }(29 \pm 12 \\
\text { y.o. })\end{array}$ & $\begin{array}{l}\text { Longitudinal study design } \\
\text { where patients were assessed } \\
\text { three times (at baseline, after } \\
10 \text { months of treatment, after } \\
30 \text { months of treatment) and } \\
\text { HC assessed twice } 35 \text { months } \\
\text { apart }\end{array}$ & $4 \mathrm{~T}$ & $\begin{array}{l}\text { SV } \\
\text { left anterior ACC and left } \\
\text { medial thalamus }(10 \times 10 \times \\
\left.15 \mathrm{~mm}^{3} \text { each }\right)\end{array}$ & Short TE (20 ms) & $\begin{array}{l}\text { Absolute relative } \\
\text { to water } \\
\text { NAA } \\
\text { Glu } \\
\text { Gln } \\
\text { GPC + PC } \\
\text { PCr + Cr } \\
\text { myo-Ins } \\
\text { Taurine } \\
\text { scyllo-Ins }\end{array}$ & $\begin{array}{l}\text { At baseline, increased Gln in } \\
\text { the left ACC } \\
\text { No significant effect for the } \\
\text { three-level repeated- } \\
\text { measures analysis } \\
\text { No correlations with clinical } \\
\text { scores }\end{array}$ \\
\hline
\end{tabular}




\begin{tabular}{|c|c|c|c|c|c|c|c|}
\hline $\begin{array}{l}\text { Uhl et al. } \\
\text { (2011) }\end{array}$ & $\begin{array}{l}24 \text { FEP }(26 \pm 6.3 \\
\text { y.o.), } 30 \text { UHR } \\
(25.6 \pm 4.5 \text { y.o. }) \\
31 \text { HC }(25.5 \pm 5.2 \\
\text { y.o.) }\end{array}$ & $\begin{array}{l}\text { Cross-sectional and investigated } \\
\text { group differences }\end{array}$ & $1.5 \mathrm{~T}$ & $\begin{array}{l}\text { SV } \\
\text { Left hippocampus, mid-sagittal } \\
\text { ACC, MPFC ( } 8 \mathrm{ml} \text { each) }\end{array}$ & $\begin{array}{l}\text { Intermediate TE } \\
\quad(140 \mathrm{~ms})\end{array}$ & $\begin{array}{l}\text { Metabolite ratios } \\
\text { GPC }+\mathrm{PC} / \mathrm{Cr} \\
\mathrm{NAA} / \mathrm{Cr}\end{array}$ & $\begin{array}{l}\text { No significant group } \\
\text { differences }\end{array}$ \\
\hline $\begin{array}{l}\text { Egerton } \\
\quad \text { et al. } \\
\quad(2012)\end{array}$ & 32 FEP ( $30 \pm 6$ y.o.) & $\begin{array}{l}\text { Cross-sectional and investigated } \\
\text { group differences }\end{array}$ & $3 \mathrm{~T}$ & $\begin{array}{l}\text { SV } \\
\text { Medial anterior ACC }(20 \times 20 \times \\
\left.20 \mathrm{~mm}^{3}\right) \text {, centre of left } \\
\text { thalamus }\left(15 \times 20 \times 20 \mathrm{~mm}^{3}\right)\end{array}$ & Short TE (30 ms) & $\begin{array}{l}\text { Metabolite ratios } \\
\text { Glu/Cr } \\
\text { Glu }+\mathrm{Gln} / \mathrm{Cr} \\
\text { NAA/Cr } \\
\text { GPC + PC/Cr } \\
\text { myo-Ins/Cr }\end{array}$ & $\begin{array}{l}\text { Increased levels of } \mathrm{Glu} / \mathrm{Cr} \text { in } \\
\text { the ACC of non-remitted } \\
\text { patients } \\
\text { Higher levels of } \mathrm{Glu} / \mathrm{Cr} \text { in } \\
\text { the anterior cingulate cortex } \\
\text { were associated with a } \\
\text { greater severity of negative } \\
\text { symptoms and a lower level } \\
\text { of global functioning }\end{array}$ \\
\hline $\begin{array}{l}\text { Tibbo et al. } \\
\quad(2013)\end{array}$ & $\begin{array}{l}33 \text { FEP }(21.6 \pm 3.4 \text { y. } \\
\text { o. }), 41 \mathrm{HC}(21.9 \pm \\
\text { 3.1 y.o. })\end{array}$ & $\begin{array}{l}\text { Cross-sectional and investigated } \\
\text { group differences }\end{array}$ & $3 \mathrm{~T}$ & $\begin{array}{l}\text { SV } \\
\text { Medial prefrontal region } \\
\text { including part of anterior } \\
\text { ACC }\left(20 \times 30 \times 30 \mathrm{~mm}^{3}\right)\end{array}$ & Short TE (20 ms) & $\begin{array}{l}\text { Absolute relative } \\
\text { to water } \\
\text { NAA } \\
\text { PCr }+ \text { Cr } \\
\text { GPC + PC } \\
\text { Glu }\end{array}$ & $\begin{array}{l}\text { A negative association was } \\
\text { found between age of } \\
\text { patients and } \mathrm{Cr} \\
16 \% \text { reduction of } \mathrm{Cr} \text { levels } \\
\text { in patients } \\
\text { No association between } \mathrm{Cr} \\
\text { and clinical variables }\end{array}$ \\
\hline $\begin{array}{l}\text { Natsubori } \\
\quad \text { et al. } \\
(2014)\end{array}$ & $\begin{array}{l}24 \text { UHR }(21.7 \pm 3.8 \\
\text { y.o.) with } 26 \\
\text { matched HC } \\
(22.3 \pm 3.2 \text { y.o.), } \\
19 \text { FEP }(25.4 \pm 6.3 \\
\text { y.o.) with } \\
19 \text { matched } \\
\text { controls ( } 26.3 \pm \\
1.5 \text { y.o.), } 25 \text { scz } \\
\text { (32.7 } \pm .6 \text { y.o.) } \\
\text { with } 28 \text { matched } \\
\text { HC (32.8 } \pm 4.3 \\
\text { y.o.) }\end{array}$ & $\begin{array}{l}\text { Cross-sectional and investigated } \\
\text { group differences }\end{array}$ & $3 \mathrm{~T}$ & $\begin{array}{l}\text { SV } \\
\text { MPFC - primarily ACC and } \\
\text { left and right paracingulate } \\
\text { gyri }\left(20 \times 20 \times 20 \mathrm{~mm}^{3}\right)\end{array}$ & Short TE (15 ms) & $\begin{array}{l}\text { Absolute relative } \\
\text { to water } \\
\text { NAA } \\
\text { Glu }+ \text { Gln } \\
\text { PCr }+\mathrm{Cr} \\
\text { GPC }+\mathrm{PC} \\
\text { myo-Ins }\end{array}$ & $\begin{array}{l}\text { Reduced levels of NAA and } \\
\text { Glu + Gln in the MPFC in } \\
\text { scz but not FEP FES or UHR }\end{array}$ \\
\hline
\end{tabular}




\begin{tabular}{|c|c|c|c|c|c|c|c|}
\hline Study & $\begin{array}{c}\text { Sample size } \\
\text { (mean age } \pm \text { S.D.) }\end{array}$ & Study design & $\begin{array}{l}\text { Field } \\
\text { strength }\end{array}$ & $\begin{array}{l}\text { SV or CSI and location } \\
\text { (voxel size) }\end{array}$ & $\begin{array}{l}\text { Short or } \\
\text { intermediate } \\
\text { Echo time } \\
\text { (TE time) }\end{array}$ & $\begin{array}{l}\text { Quantification } \\
\text { and reported }{ }^{1} \\
\text { H metabolites }\end{array}$ & $\begin{array}{l}\text { ACC results only (if possible, } \\
\text { include the effect size in } \\
\text { brackets for each } \\
\text { significant finding) }\end{array}$ \\
\hline $\begin{array}{l}\text { Dempster } \\
\text { et al. } \\
(2015)\end{array}$ & $\begin{array}{l}16 \text { FEP }(17 \pm 7.2 \\
\text { y.o. })\end{array}$ & $\begin{array}{l}\text { Longitudinal study with } \\
\text { patients assessed at baseline } \\
\text { and after } 10 \text { months }\end{array}$ & $4 \mathrm{~T}$ & $\begin{array}{l}\mathrm{SV}\left(1.5 \mathrm{~cm}^{3}\right) \\
\text { left } \mathrm{ACC} \text {, left thalamus }\end{array}$ & Short TE $(20 \mathrm{~ms})$ & $\begin{array}{l}\text { Absolute relative } \\
\text { to water } \\
\text { Glu, } \\
\text { Gln }\end{array}$ & $\begin{array}{l}\text { Baseline Gln was positively } \\
\text { associated with } \\
\text { performance on the PASAT } \\
\text { in the left ACC, } \\
\text { Glu at the 10-month } \\
\text { scanning point was } \\
\text { positively associated with } \\
\text { TrailsB duration and with } \\
\text { WCST perseverative errors } \\
\text { Glutamine at 10- month } \\
\text { scanning was positively } \\
\text { associated with WCST } \\
\text { perseverative errors and } \\
\text { negatively associated with } \\
\text { WCST }\end{array}$ \\
\hline $\begin{array}{l}\text { Smesny } \\
\text { et al. } \\
\text { (2015) }\end{array}$ & $\begin{array}{c}31 \mathrm{FEP}(25.97 \pm 4.95 \\
\text { y.o.), } 31 \mathrm{HC} \\
(25.42 \pm 5.18 \text { y.o. })\end{array}$ & $\begin{array}{l}\text { Cross-sectional and investigated } \\
\text { group differences }\end{array}$ & $3 \mathrm{~T}$ & $\begin{array}{l}\text { CSI } \\
\text { region of interest selected in } \\
\text { the frontal part of the CSI } \\
\text { slab: } 8 \text { voxels including (left } \\
\text { and right) frontal prefrontal } \\
\text { cortex and ACC }(15 \times 9 \times 1.5 \\
\left.\mathrm{cm}^{3}\right) \text { each voxel }\end{array}$ & Short TE (30 ms) & $\begin{array}{l}\text { Absolute } \\
\text { concentrations } \\
\text { Glu }\end{array}$ & $\begin{array}{l}\text { Increased levels of Glu in FEP } \\
\text { Glu positively correlated } \\
\text { with frontal/prefrontal PME } \\
\text { and right frontal/prefrontal } \\
\text { PDE in FEP and not in HC } \\
\text { Glu negatively correlated } \\
\text { with PCr or ATP values in } \\
\text { the frontal/prefrontal cortex } \\
\text { bilaterally and in the right } \\
\text { ACC in HC and not in } \\
\text { patients }\end{array}$ \\
\hline
\end{tabular}

essed at baseline

$\mathrm{V}\left(1.5 \mathrm{~cm}^{3}\right)$

MRS, magnetic resonance spectroscopy; FEP, first episode psychosis; SV, single voxel; CSI, chemical shift imaging; HC, healthy controls; SCZ, schizophrenia; WM, white matter; GM, gray matter; CSF, cerebro-spinal fluid; ACC, anterior cingulate cortex; DLPFC, dorsolateral prefrontal cortex; MPFC, medial prefrontal cortex; NAA, N-acetylaspartate; NAAG, N-acetylaspartylglutamate; Gln, glutamine; Glu, glutamate; Glc, glucose; PCr + Cr, phosphocreatine + creatine; GPC + PC, glycerophosphocholine + phosphocholine; mI, myo-Inositol; myo-Ins, myo-inositol; scyllo-Ins, scyllo-Inositol; TE, echo time; y.o., years old. 
studies found preserved concentrations. Moreover, results in FEP do not fully overlap with those in chronic schizophrenia. This could be due to the fact that metabolite levels are particularly sensitive to the characteristics of the sample, and to the phase of disease. Therefore, although glutamatergic neurotransmission may play a role in the pathophysiology of psychosis onset, the fact that findings are somewhat heterogeneous suggests that a more in-depth investigation is needed to shed light on the glutamatergic processes related to psychosis, by implementing larger longitudinal studies of FEP using ultra high field MR scanners.

\section{Financial Support}

Professor Brambilla (RF-2011-02352308) and Dr Bellani (GR-2010-2319022) were partly supported by grants from the Italian Ministry of Health. Dr Stanley was supported, in part, by the Lycaki-Young Funds from the State of Michigan.

\section{Conflict of Interest}

None.

\section{Ethical Standard}

The authors declare that no human or animal experimentation was conducted for this work.

\section{References}

Altamura AC, Buoli M, Caldiroli A, Caron L, Cumerlato Melter C, Dobrea C, Cigliobianco M, Zanelli Quarantini F (2015). Misdiagnosis, duration of untreated illness (DUI) and outcome in bipolar patients with psychotic symptoms: a naturalistic study. Journal of Affective Disorders 182, $70-75$.

Baiano M, David A, Versace A, Churchill R, Balestrieri M, Brambilla P (2007). Anterior cingulate volumes in schizophrenia: a systematic review and a meta-analysis of MRI studies. Schizophrenia Research 93, 1-12.

Benes FM, Berretta S (2001). GABAergic interneurons: implications for understanding schizophrenia and bipolar disorder. Neuropsychopharmacology 25, 1-27.

Bersani FS, Minichino A, Fojanesi M, Gallo M, Maglio G, Valeriani G, Biondi M, Fitzgerald PB (2014). Cingulate Cortex in Schizophrenia: its relation with negative symptoms and psychotic onset. A review study. European Review for Medical and Pharmacological Sciences 18, 33543367.
Blasi G, Bertolino A, Brudaglio F, Sciota D, Altamura M, Antonucci N, Scarabino T, Weinberger DR, Nardini M (2004). Hippocampal neurochemical pathology in patients at first episode of affective psychosis: a proton magnetic resonance spectroscopic imaging study. Psychiatry Research 131, 95-105.

Brambilla P, Stanley JA, Nicoletti MA, Sassi RB, Mallinger AG, Frank E, Kupfer D, Keshavan MS, Soares JC (2005). $1 \mathrm{H}$ magnetic resonance spectroscopy investigation of the dorsolateral prefrontal cortex in bipolar disorder patients. Journal of Affective Disorders 86, 61-67.

Dempster K, Norman R, Théberge J, Densmore M, Schaefer B, Williamson P (2015). Glutamatergic metabolite correlations with neuropsychological tests in first episode schizophrenia. Psychiatry Research 233, 180-185.

Egerton A, Brugger S, Raffin M, Barker GJ, Lythgoe DJ, McGuire PK, Stone JM (2012). Anterior cingulate glutamate levels related to clinical status following treatment in first-episode schizophrenia.

Neuropsychopharmacology 37, 2515-2521.

Galinska B, Szulc A, Tarasow E, Kubas B, Dzienis W, Czernikiewicz A, Walecki J (2009). Duration of untreated psychosis and proton magnetic resonance spectroscopy (1H-MRS) findings in first-episode schizophrenia. Medical Science Monitor 15, CR82-CR88

Hardy CJ, Tal A, Babb JS, Perry NN, Messinger JW, Antonius D, Malaspina D, Gonen O (2011). Multivoxel proton MR spectroscopy used to distinguish anterior cingulate metabolic abnormalities in patients with schizophrenia. Radiology 261, 542-550.

Kraguljac NV, Reid M, White D, Jones R, den Hollander J, Lowman D, Lahti AC (2012). Neurometabolites in schizophrenia and bipolar disorder - a systematic review and meta-analysis. Psychiatry Research 203, 111-125.

Marsman A, van den Heuvel MP, Klomp DW, Kahn RS, Luijten PR, Hulshoff Pol HE (2013). Glutamate in schizophrenia: a focused review and meta-analysis of ${ }^{1} \mathrm{H}$ MRS studies. Schizophrenia Bulletin 39, 120-129.

Merritt K, McGuire P, Egerton A (2013). Relationship between glutamate dysfunction and symptoms and cognitive function in psychosis. Frontiers in Psychiatry 4, 151 .

Natsubori T, Inoue $\mathrm{H}$, Abe O, Takano $\mathrm{Y}$, Iwashiro N, Aoki Y, Koike S, Yahata N, Katsura M, Gonoi W, Sasaki H, Takao H, Kasai K, Yamasue H (2014). Reduced frontal glutamate + glutamine and $\mathrm{N}$-acetylaspartate levels in patients with chronic schizophrenia but not in those at clinical high risk for psychosis or with first-episode schizophrenia. Schizophrenia Bulletin 40, 1128-1139.

Smesny S, Gussew A, Biesel NJ, Schack S, Walther M, Rzanny R, Milleit B, Gaser C, Sobanski T, Schultz CC, Amminger P, Hipler UC, Sauer H, Reichenbach JR (2015). Glutamatergic dysfunction linked to energy and membrane lipid metabolism in frontal and anterior cingulate cortices of never treated first-episode schizophrenia patients. Schizophrenia Research 168, 322-329.

Squarcina L, Perlini C, Peruzzo D, Castellani U, Marinelli V, Bellani M, Rambaldelli G, Lasalvia A, Tosato S, De 
Santi K, Spagnolli F, Cerini R, Ruggeri M, Brambilla P (2015). The use of dynamic susceptibility contrast (DSC) MRI to automatically classify patients with first episode psychosis. Schizophrenia Research 165, 38-44.

Stanley JA (2002). In vivo magnetic resonance spectroscopy and its application to neuropsychiatric disorders. Canadian Journal of Psychiatry 47, 315-326.

Stanley JA, Vemulapalli M, Nutche J, Montrose DM, Sweeney JA, Pettegrew JW, MacMaster FP, Keshavan MS (2007). Reduced N-acetyl-aspartate levels in schizophrenia patients with a younger onset age: a single-voxel $1 \mathrm{H}$ spectroscopy study. Schizophrenia Research 93, 23-32.

Théberge J, Bartha R, Drost DJ, Menon RS, Malla A, Takhar J, Neufeld RW, Rogers J, Pavlosky W, Schaefer B, Densmore M, Al-Semaan Y, Williamson PC (2002). Glutamate and glutamine measured with $4.0 \mathrm{~T}$ proton MRS in never-treated patients with schizophrenia and healthy volunteers. American Journal of Psychiatry 159, 1944-1946.

Théberge J, Al-Semaan Y, Williamson PC, Menon RS, Neufeld RW, Rajakumar N, Schaefer B, Densmore M, Drost DJ (2003). Glutamate and glutamine in the anterior cingulate and thalamus of medicated patients with chronic schizophrenia and healthy comparison subjects measured with 4.0-T proton MRS. American Journal of Psychiatry 160, 2231-2233.
Théberge J, Al-Semaan Y, Drost DJ, Malla AK, Neufeld RW, Bartha R, Manchanda R, Menon R, Densmore M, Schaefer B, Williamson PC (2004). Duration of untreated psychosis vs. N-acetylaspartate and choline in first episode schizophrenia: a $1 \mathrm{H}$ magnetic resonance spectroscopy study at 4.0 Tesla. Psychiatry Research 131, 107-114.

Théberge J, Williamson KE, Aoyama N, Drost DJ, Manchanda R, Malla AK, Northcott S, Menon RS, Neufeld RW, Rajakumar N, Pavlosky W, Densmore M, Schaefer B, Williamson PC (2007). Longitudinal greymatter and glutamatergic losses in first-episode schizophrenia. British Journal of Psychiatry 191, 325-334.

Tibbo PG, Bernier D, Hanstock CC, Seres P, Lakusta B, Purdon SE (2013). 3-T proton magnetic spectroscopy in unmedicated first episode psychosis: a focus on creatine. Magnetic Resonance in Medicine 69, 613-620.

Uhl I, Mavrogiorgou P, Norra C, Forstreuter F, Scheel M, Witthaus H, Ozgürdal S, Gudlowski Y, Bohner G, Gallinat J, Klingebiel R, Heinz A, Juckel G (2011). 1 H-MR spectroscopy in ultra-high risk and first episode stages of schizophrenia. Journal of Psychiatric Research 45, 1135-1139.

Zabala A, Sánchez-González J, Parellada M, Moreno DM, Reig S, Burdalo MT, Robles O, Desco M, Arango C (2007). Findings of proton magnetic resonance spectometry in the dorsolateral prefrontal cortex in adolescents with first episodes of psychosis. Psychiatry Research 156, 33-42. 